\title{
A Fundamentals of Financial Accounting Course Multimedia Teaching System based on Dokeos and BigBlueButton
}

\author{
https://doi.org/10.3991/ijet.v13i05.8433 \\ Wen Han \\ ZiBo Vocational Institute, ZiBo, China \\ wenwen 8130 esina.com
}

\begin{abstract}
Multi-media technology plays a critical role in modern remote education development, which can make abstract and complicated teaching content more concrete and fully mobilize students' activity, enrich the teaching resources of remote education, break through the space-time limitation of traditional education, and meanwhile strengthen the interaction of remote education. Currently ordinary remote teaching system based on Dekeos and Bigbluebutton without self-detection function requires for professional personnel's regular examination and maintenance. It takes long time and large workload, brings inconvenience for schools and teachers in remote education. Meanwhile, it also has the problem of disjoint between teaching and practice. This paper has designed a multimedia teaching system based on Dokeos and BigBlueButton to apply to "Fundamentals of Financial Accounting" course including abundant remote education functions such as recording and replaying, desk sharing, video session, PPT presentation. Student condition online inspection device of remote education based on decision-making tree has solved the problem existing in current remote teaching system that it cannot automatically inspect device, thus to further optimize the process of remote education.
\end{abstract}

Keywords-Dekeos, BigBlueButton, Multi-media technology, Financial Accounting course

\section{$1 \quad$ Introduction}

Remote education is a network teaching mode emerging with the maturity of multimedia technology and computer technology, which has brought fundamental change to traditional learning process by virtue of multi-media technology so that students and teachers are not limited to fixed time and space for interaction and students can realize independent study through network [1]. Commonly used multi-media technology in remote education includes two application forms. First, teachers provide text, images and other teaching resources to network teaching system for students' login to browse and search. The second one is to realize teacher-student bilateral interaction and communication through email, forum and social media software. In addition, 
video conference system is also a multi-media technology usually selected in remote education [2].

With the gradual increase in popularity of remote education, people have higher requirements for remote teaching system and previous unitary system has reflected some problems. People hope that remote teaching system with automatic management and remote interaction processing functions can automatically complete teaching tasks and realize student-teacher interaction more smoothly. Under this background, remote teaching system based on Dokeos and BigBlueButton has become the highquality choice for modern remote education due to its diversified functions, simplified operation and high extensibility and connectivity.

Based on analysis of domestic and overseas research, this paper introduces multimedia technology based on Dokeos [3] and BigBlueButton [4] to design a remote teaching system for "Fundamentals of Financial Accounting" course, and also conducted tests on system practical teaching effect. Remote teaching system designed in this article has standard course management function, and the function of on-line monitoring students' condition based on decision-making tree, which has provided feasible channel for improving remote education system.

\section{State of the art}

In recent years, remote education represented by accounting, business and other specialty teaching is in continuous demand. People prefer to obtain relevant knowledge through network teaching so as to satisfy life and work demands. Due to great difference in original knowledge reservation and reception capability, remote teaching effect on accounting and business courses are different. Domestic and overseas scholars have shift research focus to multimedia technology improvement under remote educational background. Some scholars have analyzed the application effect of multi-media technology in remote education and believed that remote education can develop without multi-media technology which can enrich teaching methods and provide more independent space [5]. Jia et al. have made demand analysis on remote education system function demand with technical colleges as the example and believed that remote education will become modern education development direction in short time, thus it is critical to improve remote education related teaching system and multi-media technology [6]. Improvement and integration of multimedia technology applied in remote education has become a widely concerned issue at home and abroad.

Based on the difference of current remote education, some scholars have made preliminary design of remote education system based on Dokeos and BigBlueButton and tried to construction an individualized and intelligent network teaching system. For example, researches have constructed Educational Psychological Dekeos course platform and realized the function of online collaborative learning and multiple evaluation learning effect. Practice shows that, Dekeos can satisfy basic requirements of collaborative learning with a significant effect for teaching effect improvement [7]. Some researchers have designed remote education system based on Dokeos and 
BigBlueButton basically equipped with course management, streaming media display, video session and online interaction function. On this basis, the scholar has tested system functions and provided feasible improvement methods to solve problems in the system [8]. Fallery et al. has designed and implemented a BigBlueButton based video conference system based on the customer's demand in Neusoft Group and realized high-efficiency HD teleconference and office work, to improve user's communication efficiency and management performance. Due to these advantages, it has become a new model of remote tele-office and provided good reference for the design in this paper [9]. Many scholars' researches show that remote education system based on Dokeos and BigBlueButton can satisfy the basic requirements of modern remote teaching, suitable for accounting [10], business and other specialty teaching, and it will become a development trend of network teaching system.

However, there are some defects in remote teaching system based on Dokeos and BigBlueButton. Firstly, there exist a disjoint between teaching and practice. The society has higher practical ability requirements for students in vocational or medical colleges which focus on theory in their remote education so as to obvious detach with students' professional practice. Secondly, self-detection is not available for remote education system which requires for professional personnel to regularly inspect and repair and it will take long time and large workload to bring inconvenience for schools and teachers to conduct remote education [11]. The teaching system designed in this paper has been applied into a students' condition online remote monitoring device based on decision-making tree equipped with remote education course management, students' information management, video management and online course setup to improve the difficult time-consuming detection problem of current remote education device. The accessory detection device has high sensitivity and good stability. Meanwhile, an independent practical module has been designed in this education system to strengthen practical education.

\section{Theoretical construction}

\subsection{Dokeos and BigBlueButton}

Dokeos [12]is a teaching and course management system in open source network based on OSS standard and developed by PHP language to allow instructors to manage and create course websites in Explorer, Opera and other browsers supporting 34 world mainstream language interfaces including simplified Chinese. Dekeos system usually with LINUX as operation environment applies MySQL database to store backstage data. Foreground web server applies Appache loading PHPS analysis interface to support software with characteristics of stable operation and high security. Dokeos system includes procedures and activities required in training process such as course setup, collaborative learning, and course management, so as to effectively create and manage training activities. Meanwhile, in the friendly system interface, users can operate freely after simple training for file uploading, courseware production, announcement release and other teaching auxiliary activities. 
BigBlueButton[13] is a system providing virtual classroom function containing five modules: BigBlueButton-apps, BigBlueButton-client, BigBlu-ebutton-web, deskshare-app and deskshare-applet. BigBlueButton-apps is the web application program of streaming media server Red5, BigBlueButton-client is the Flex/Flash client end, BigBlu-ebutton-web is the web application program of Grails framework for meeting arrangement and turnover record. deskshare-app is the desk sharing part of streaming media server Red5, and deskshare-applet is the Applet program to capture desk. Through BigBlueButton, teachers can instruct courses online and students can learn through network. So, it has broken through the limitation of time and space in traditional education [6]. BigBlueButton overall framework diagram see Fig 1.

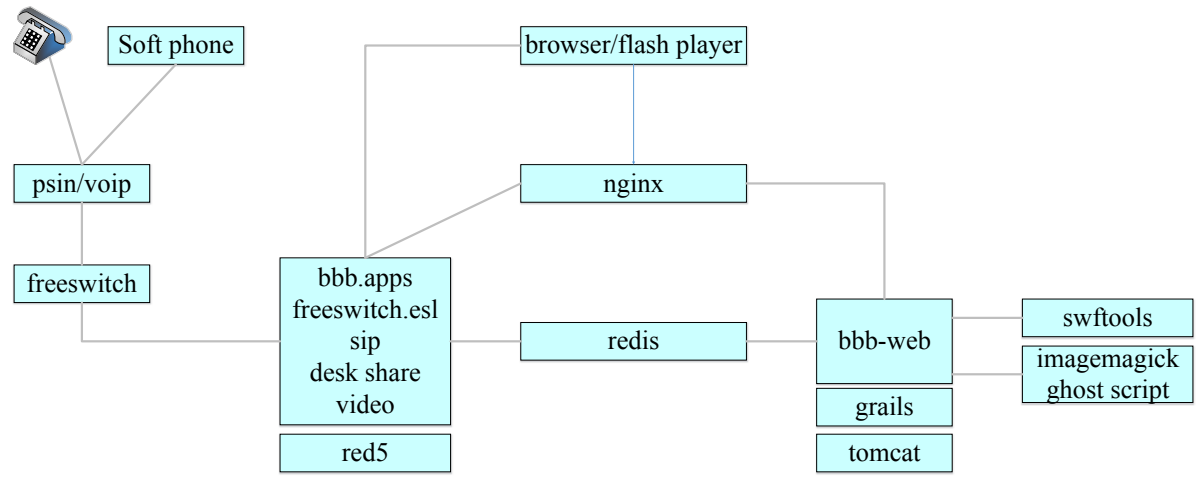

Fig. 1. BigBlueButton overall framework diagram

From Fig. 1 courseware, remote teaching system based on Dokeos and BigBlueButton designed in this paper can provide different functions for all subjects participating in network teaching such as online teaching and course management for teachers, online consultation and participation in online classroom for students. Dokeos can well integrate BigBlueButton system to construct remote teaching platform suitable for network teaching.

\subsection{Remote teaching system structure}

Overall structure of remote teaching system based on Dokeos and BigBlueButton designed in this paper is as Fig 2.

It can be seen from Fig 2 that, remote teaching system is made by Dokeos, MySQL database and BigBlueButton for students to enter into system in browsers for learning. Dekeos is the core of the system, as well as the foundation to realize course management, student management, courseware management and other remote management. It can establish virtual classroom through invoking BigBlueButton to realize network teaching and online Q\&A.

BigBlueButton is mainly composed by 14 open-sourcing software including voice conference server, desk sharing application program and videoconferencing program, etc. Specifically, in client framework, BigBlueButton can realize real-time interaction 
through Flash language. Take teachers' transmitting PPT to server as the example, the process is shown in Fig 3.

It can be seen from Fig 3 that teachers firstly transmit PDF format files to Nginx server and then send requests to $b b b-23 b$; then use swf2pdf to produce $s w f$ format file and then send the conversion progress to client end and teachers. Nginx is system agent server. Redis is responsible for transmitting information between $b b b$-web and bbb-apps.

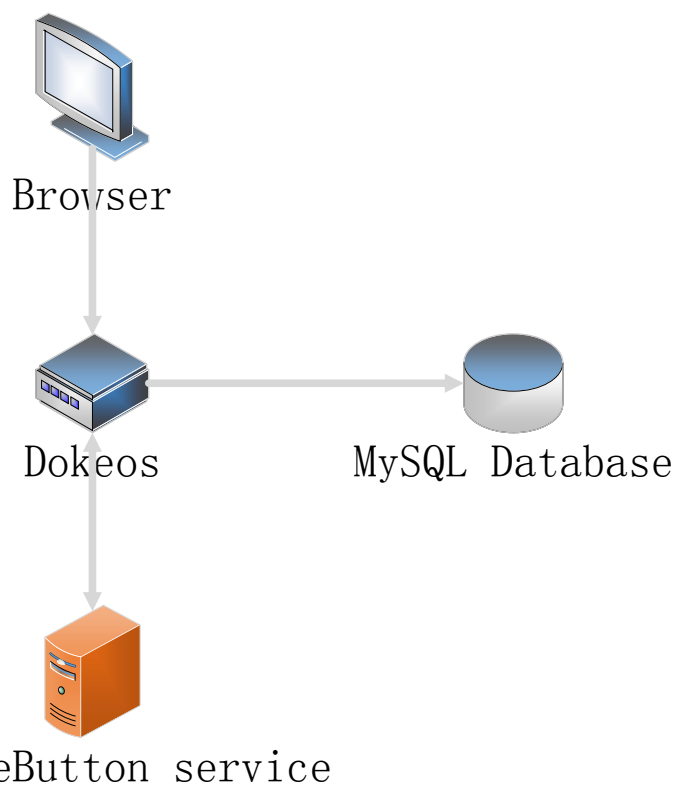

Fig. 2. Remote teaching system overall structure

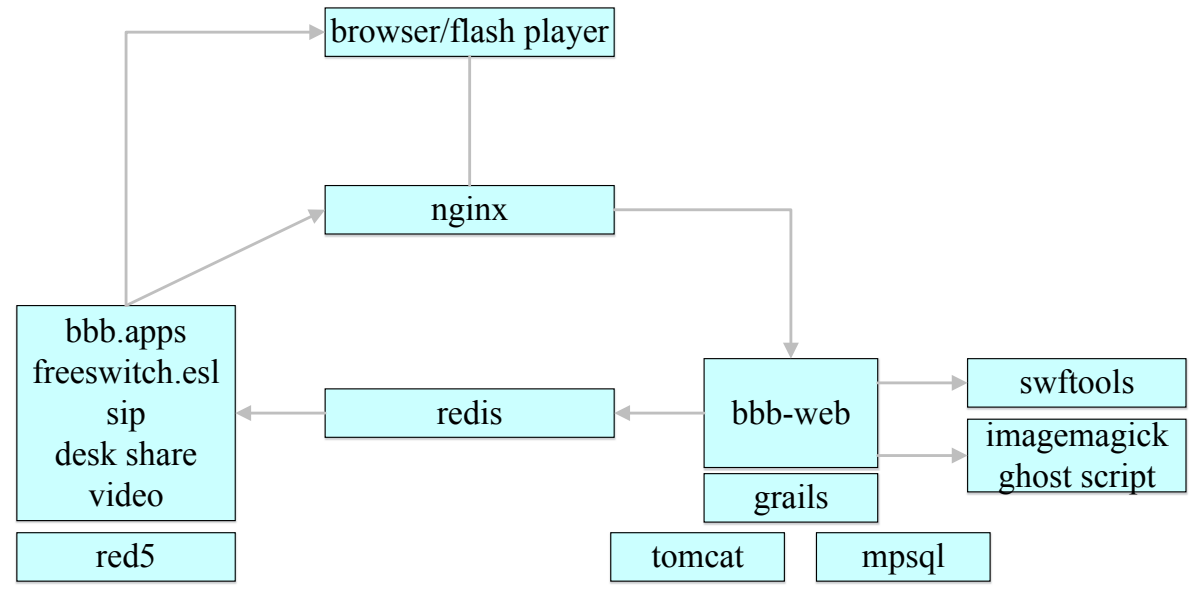

Fig. 3. Process of uploading PPT to server 


\section{Construction of "Fundamentals of Financial Accounting" course multimedia teaching system based on Dokeos and BigBlueButton}

\subsection{Module decomposition and definition}

On the basis of completing remote education system structure, this paper has conducted system function design, shown in Fig 4.

It can be seen from Fig 4 that, OSS Dekeos can provide courseware, videos, teaching monitoring, exams and evaluation functions. BigBlueButton is responsible for providing virtual classroom functions to realize online teaching. Remote teaching system based on Dokeos and BigBlueButton in this paper will provide necessary functions for teachers and students respectively. Detailed design is as follows:

First is Dokeos based online education and course management system function design. Users can conduct next-step operation after logging in system. Users can log in system after inputting preset user name and passwords and then enter into function interface.

It can be seen from Fig 5 that the left corner of the interface shows user's basic information. The left modules are "my task", "practical training chapter", "exam system" and "resource management". "My task" module is student's ongoing learning activity including video and lecture. In the left side of lecture are attached note and practice button for students to record and test conveniently. An exam system shows recent exam arrangement and exam results. Resource management module contains some teaching resources connected with remote education system.

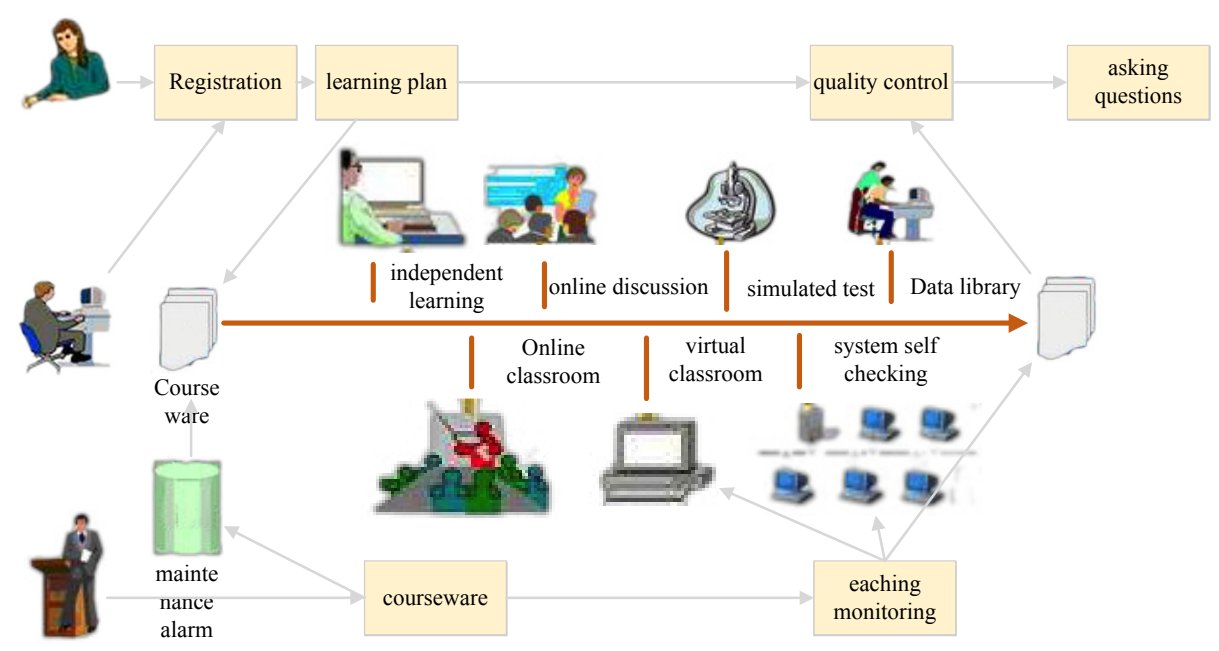

Fig. 4. Distance education system function design 

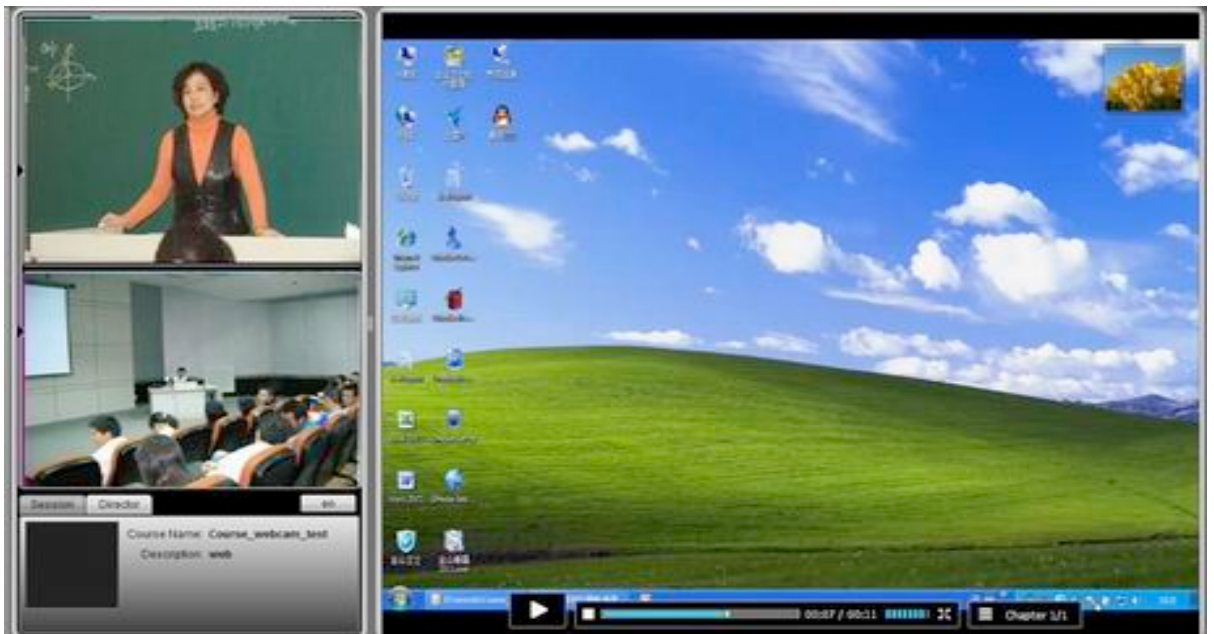

Fig. 5. Remote teaching system application diagram

The second is BigBlueButton function design. Multi-media technology based on BigBlueButton has realized the combination of virtual classroom with Dokeos. Teachers and students can operate different roles after entering into virtual classroom for instruction and lecture-listening activities. Interface is shown in Fig 6.

It can be seen from Fig 6 that in teacher-student interaction display in the remote education system, teachers and students can enter into classroom from virtual classroom interface which includes user list, attender's list, video area, PPT display area, text chatting and white board. In the left of interface are video area, use list and attender list from top to bottom; in the lower right is text chatting and white board. If users have logged in, they can selectively choose group chatting or private chatting function. In teacher end interface, teacher can click desk sharing button to achieve desk real-time sharing.

Meanwhile, the on-line monitoring students' condition based on decision-making tree has been added into remote education system. In the structure, use display screen to fix the connection frame which is connected with case. The maintenance panel is in flexible connection with case and the detection device is connected with case. Detection device is composed by fixed plate, detector, processor, and indicator light. Connect detector with circuit board which is equipped with detector to connect the indicator light on the shell. Flexibly connect wire with wiring board and connect driver with case. The purpose of this is to construct the detection device of remote education system for automatically detecting device operation with no need of regular detection by maintenance personnel. It takes short time and small workload, has high sensitivity and stability.

Remote teaching system based on Dokeos and BigBlueButton designed in this paper can realize the functions of course management, student information management and video management required by remote education. It can also achieve the function of virtual classroom on the basis of BigBlueButton system for students' real-time listening to lecture and interaction with teachers for course questions. 


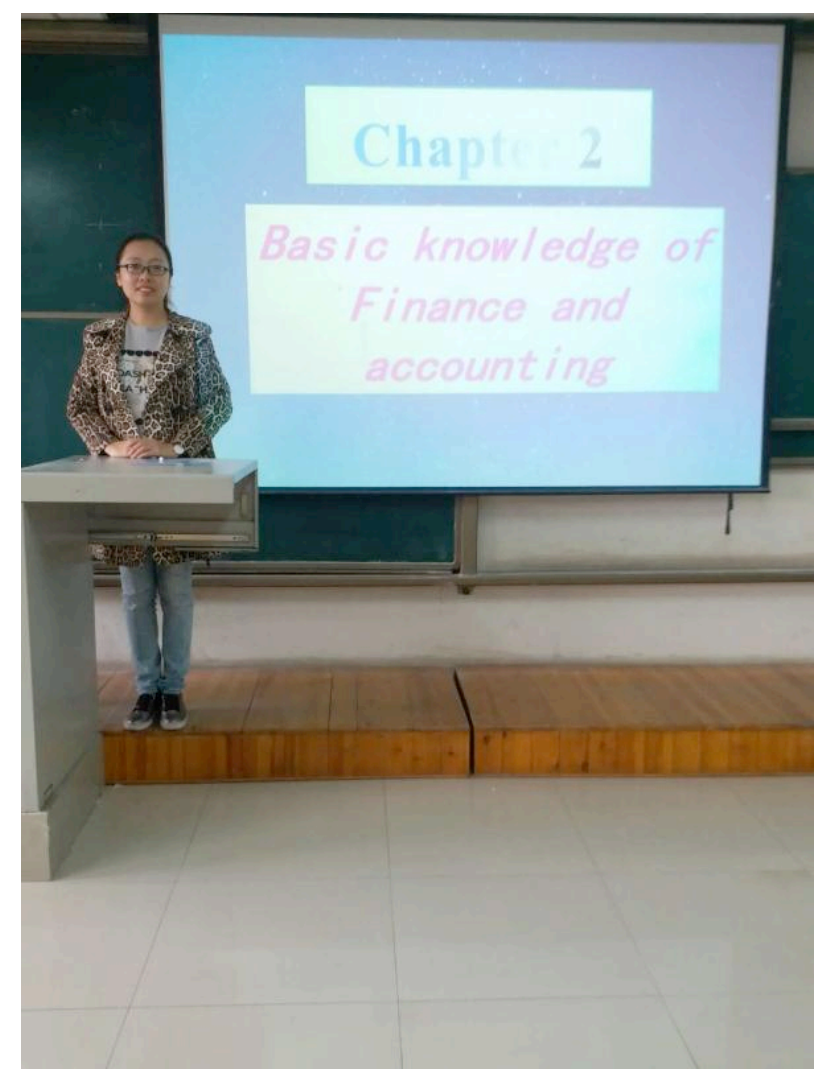

Fig. 6. Teacher-student interaction display in remote education system

\subsection{Remote teaching system function realization}

As Dekeos is equipped with standard course management function, it can be appropriately improved on the basis of original system to satisfy the teaching requirement of "Fundamentals of Financial Accounting" course. So remote education system functions can be achieved mainly by carrying out BigBlueButton.

The key to realize the virtual classroom function of BigBlueButton is streaming media technology. Usually Red5 is used as the streaming media server, RTMP as the streaming media transmission protocol to provide stable video streaming for Adobe Flash Player and other client ends. In current environment, Red5 has widespread application. Among five modules of BigBlueButton, BigBlueButton-apps module as the web application program of streaming media server Red 5 to process the real-time interaction between system and client end including PPP presentation, resource sharing and teacher-student interaction.

In Red5 based develop application programs, the most important configuration file is web.xml including webAppRootKey, contextConfigLocation, globalScope, locatorFactorySelector, parentContextKey and other parameters. 


\subsection{Effect check}

With "Fundamentals of Financial Accounting" course as the experiment course with total 12 class hours, 46 sophomore students in the accounting school of a college as the experiment object, conduct experiment by dividing experiment object into control group and experiment group for comparative analysis. Learning content is mainly about theoretical knowledge. After the end of class hours, conduct comparative analysis on experiment class receiving Dokeos and BigBlueButton multi-media technology and control class receiving traditional multi-media technology, with the collaboration of researchers and practitioners as the basis of experiment orderly operation. Course teaching progress will be proceeded in the order of chapter. Students in experiment group will study in virtual class for interactive communication through remote education system. Students will provide learning effect feedback after each class through remote education system. In the middle and the end of a term, students should fill in questionnaires based on their practical condition to guarantee the validity of survey results. Questions in the questionnaire include function frequency, evaluation on the teaching organizational form, evaluation on learning content, advantages and disadvantages of remote education system, and satisfaction survey, etc.

After a period of study, multi-media technology based on Dokeos and BigBlueButton has played an important role in "Fundamentals of Financial Accounting" remote teaching. Students will receive different forms of learning resources such as audio, video and picture for mutual communication and timely feedback. Analysis on students' satisfaction through questionnaire survey and interview show that students' satisfaction of the teaching organizational form and learning content is above $90 \%$, much higher than students' satisfaction in control group. Students' overall evaluation survey on the teaching organizational form and learning content of "Fundamentals of Financial Accounting" is shown in Fig 7.

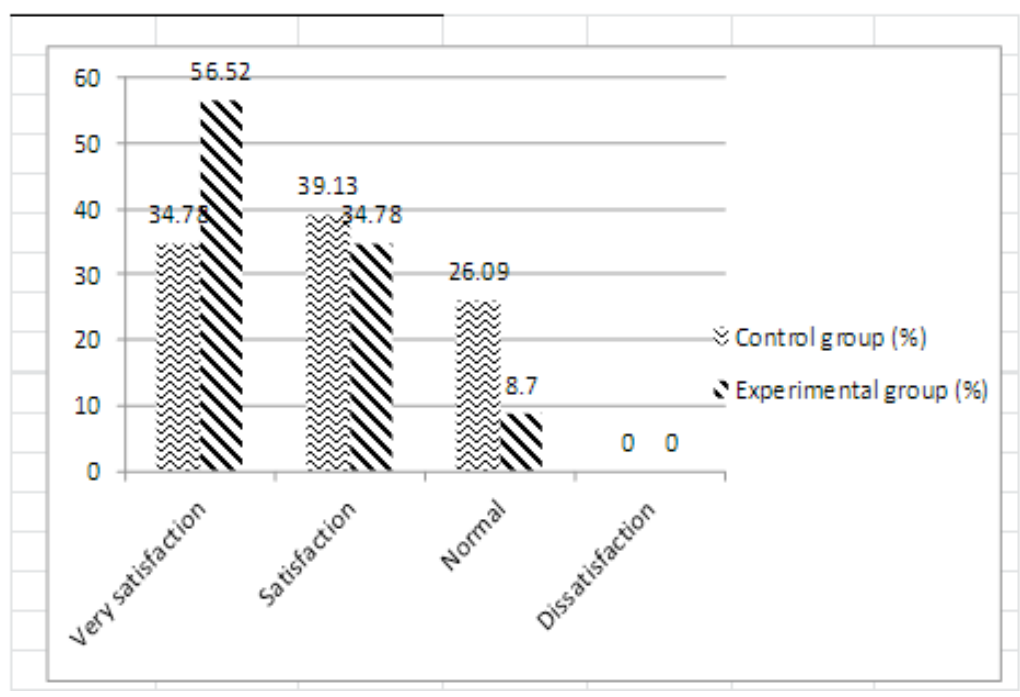

Fig. 7. Students' overall evaluation on teaching organizational form and learning content 
It can be seen from Fig 7 that, in "quite satisfied", students in experiment account for $56.52 \%$ but the number in control group is only $34.78 \%$. The difference is significant. As a whole, the proportion of students feel very satisfied with teaching organizational form and learning content is obviously higher than control group. Students' recognition of remote education system based on Dokeos and BigBlueButton is higher.

Specifically, in students' interest cultivation, statistics of students' learning interest in finance and account basic knowledge before and after experiment is shown in table 1.

Table 1. Students' interest in finance and accounting knowledge learning $(\mathrm{N}=46)$

\begin{tabular}{|l|l|c|c|c|c|c|}
\hline \multicolumn{2}{|c|}{ Group } & $\begin{array}{c}\text { Very interest- } \\
\text { ed }\end{array}$ & $\begin{array}{c}\text { More interest- } \\
\text { ed }\end{array}$ & General & $\begin{array}{c}\text { Not very inter- } \\
\text { ested }\end{array}$ & $\begin{array}{c}\text { Not interested } \\
\text { at all }\end{array}$ \\
\hline \multirow{2}{*}{ Control group } & Before & 1 & 9 & 11 & 2 & 0 \\
\cline { 2 - 7 } & After & 3 & 13 & 6 & 1 & 0 \\
\hline \multirow{2}{*}{$\begin{array}{l}\text { Experiment } \\
\text { group }\end{array}$} & Before & 0 & 11 & 11 & 1 & 0 \\
\cline { 2 - 7 } & After & 7 & 12 & 4 & 0 & 0 \\
\hline
\end{tabular}

It can be seen from table 1 that students in experiment significantly have improved their learning interest in finance and account basic knowledge. In experiment group, no students were interested in the course before experiment, 11 students felt fair about the course. 7 students are interested in the course after experiment, accounting for $20 \%$. The number of students feel fair about course reduces from 11 to 4 .

Investigation shows that students widely believe that multi-media technology based on Dokeos and BigBleButton has a significant enhancement effect in "Fundamentals of Financial Accounting" course, has a great promoting effect on their independent study and all-round improvement and practical ability. Through remote education system based on Dokeos and BigBlueButton, students interact with each other more and get more colorful resources, conveniently obtain information, and significantly improve their learning effect. Advantages of virtual classroom such as strong interaction, convenient information obtaining, and abundant resources have been widely acknowledged. It can fully mobilize students' activity. Most students who have participated in course learning think it is the first remote learning supporting tool for a specific course and they are deeply impressed by its advantage of expanding knowledge. In addition, most students think multi-media technology end device based on Dokeos and BigBlueButton is suitable for distance learning. Introduction of detection device is critical for smooth remote education. It can effectively avoid equipment failure, poor exhibition effect and other problems.

\section{Conclusions}

It is of great significance to introduce multi-media technology based on Dokeos and BigBlueButton to "Fundamentals of Financial Accounting" course teaching. Most students are satisfied with the teaching organizational form and teaching content of 
the new type multi-media. Multi-media technology based on Dokeos and BigBlueButton can realize abundant remote educational functions including recording and playback, desk sharing, video session, PPT presentation, etc. On-line monitoring students' condition based on decision-making tree can solve the problem existing in current remote teaching system that it cannot automatically inspect device, thus to further optimize the process of remote education. To sum up, multi-media technology based on Dokeos and BigBlueButton can effectively solve problems existing in current remote education system such as poor interaction and single mode, in accordance with the development trend of individualized and intelligent remote education. The development of multi-media technology based on Dokeos and BigBlueButton will provide new concept for remote education system improvement and then to gradually construct a remote education system with higher teaching efficiency and strong teacher-student interaction.

\section{References}

[1] Anderson, T, Dron, J. Three Generations of Distance Education Pedagogy. Distance Education in China, 2013, vol. 12(3), pp. 80-97.

[2] Chávez Arcega, M.A. Reseña de" Teaching and learning at a distance: Foundations of distance education. Revista Mexicana de Investigación Educativa, (2011), vol. 16(48), pp. 301-306.

[3] Vasilenko, E.A., Meshcheryakova, T.V., Kol'Tsova, E.M., et al. The development of information-education materials for systems of distance learning: "Protection of Intellectual Property," an example of a course of study. Scientific \& Technical Information Processing, 2011, vol. 38(3), pp. 193-200. https://doi.org/10.3103/S0147688211030166

[4] Ayaz, M.F., Oral, B. The Determination of Teacher Candidates' Opinions about Multicultural Education. Journal of Humanities \& Social Sciences, 2016, vol. 21(2), pp. 36-45.

[5] Kiker, J. Develop Education Systems that Integrate All Levels. Techniques Connecting Education \& Careers, 2007, vol. 82, pp. 38-41.

[6] Jia, X.T. Demand Analysis of Distance Education System in "Internet+" Era - A Case Study of Qiongtai Teachers College. Software Guide, 2016, vol. 15(6), pp. 81-82.

[7] Yang, G.Y., Wang, S.Q. Add Interactive Voice and Video Virtual Classroom for Blackboard Based on BigBlueButton. Computer Engineering \& Software, 2016, vol. 37 (10), pp. $1-6$

[8] VelÁ, A., Squez, M. Desarrollo de la comprensión oral del idioma inglés a través del aprendizaje combinado B-learning en estudiantes universitarios. Universitas Revista De Ciencias Sociales Y Humanas, 2015, vol. 23, pp. 109-124.

[9] Fallery, B., Gerbaix, S., \& Ologeanu, R. A Comparison Between "Virtual Class" and "Remote Class". Post-Print, 2013, vol. 25(1), pp. 440 - 445.

[10] Pearson, C.A., \& Chatterjee, S.R. Extending business education beyond traditional boundaries: A case study in negotiated problem resolution in a remote regional indigenous community in Australia. Journal of Teaching in International Business, 2010, vol. 21(4), pp. 307-328. https://doi.org/10.1080/08975930.2010.526029

[11] Lowrie, T., Jorgensen, R. Teaching mathematics remotely: changed practices in distance education. Mathematics Education Research Journal, 2012, vol. 24(3), pp. 371-383. https://doi.org/10.1007/s13394-011-0031-2 
Paper-A Fundamentals of Financial Accounting Course Multimedia Teaching System based on Dok...

[12] Awad, L.N., Reisman, D.S., Bindermacleod, S.A. Do Improvements in Balance Relate to Improvements in Long-Distance Walking Function after Stroke?. Stroke Research \& Treatment, 2014, pp. 184-189. https://doi.org/10.1155/2014/646230

[13] Tro Morató, T. Telecollaboration for intercultural language acquisition: analysis of secondary education pupils' discourses in chat and videoconference format within the Telecollaboration for Intercultural Language Acquisition (TILA) framework. Landscape Ecology, 2015, vol. 26(2), pp. 211-224.

\section{$7 \quad$ Author}

Wen Han is a Lecturer in ZiBo Vocational Institute, ZiBo 255314, China (wenwen8130@sina.com).

Article submitted 13 February 2018. Resubmitted 18 March 2018. Final acceptance 27 March 2018. Final version published as submitted by the author. 